\title{
MDMA modifies active avoidance learning and recall in mice
}

\author{
José Manuel Trigo • Araceli Cabrero-Castel · \\ Fernando Berrendero • Rafael Maldonado • \\ Patricia Robledo
}

Published online: 11 July 2008

(C) Springer-Verlag 2008

Erratum to: Psychopharmacology (2008)197:391-400

DOI 10.1007/s00213-007-1045-Z

In the above article the Figs. 1, 2, 4 and 5 include symbols which are not explained in the legends. Here are the corrected legends.

\footnotetext{
The online version of the original article can be found at http://dx.doi. org/10.1007/s00213-007-1045-Z.

J. M. Trigo • A. Cabrero-Castel • F. Berrendero • R. Maldonado •

P. Robledo

Laboratori de Neurofarmacologia,

Departament de Ciències Experimentals i de la Salut,

Universitat Pompeu Fabra,

Barcelona, Spain

P. Robledo

e-mail: patricia.robledo@upf.edu

P. Robledo

Institut Municipal d'Investigació Mèdica (IMIM),

Barcelona, Spain

R. Maldonado $(\square)$

Universitat Pompeu Fabra,

Calle Dr. Aiguader, 88,

08003 Barcelona, Spain

e-mail: rafael.maldonado@upf.edu
} 


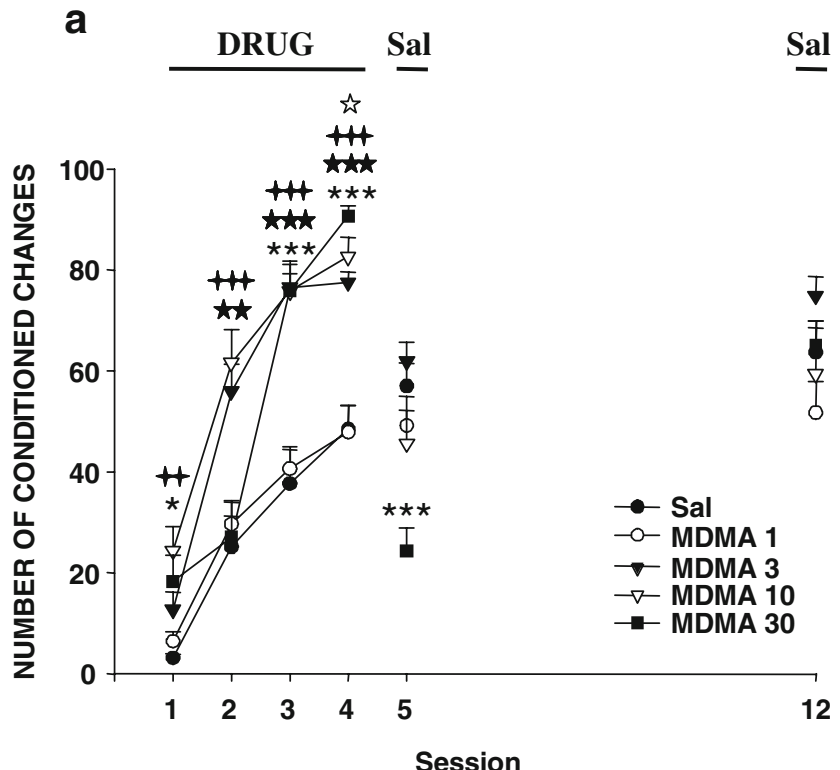

b DRUG Sal

Sal

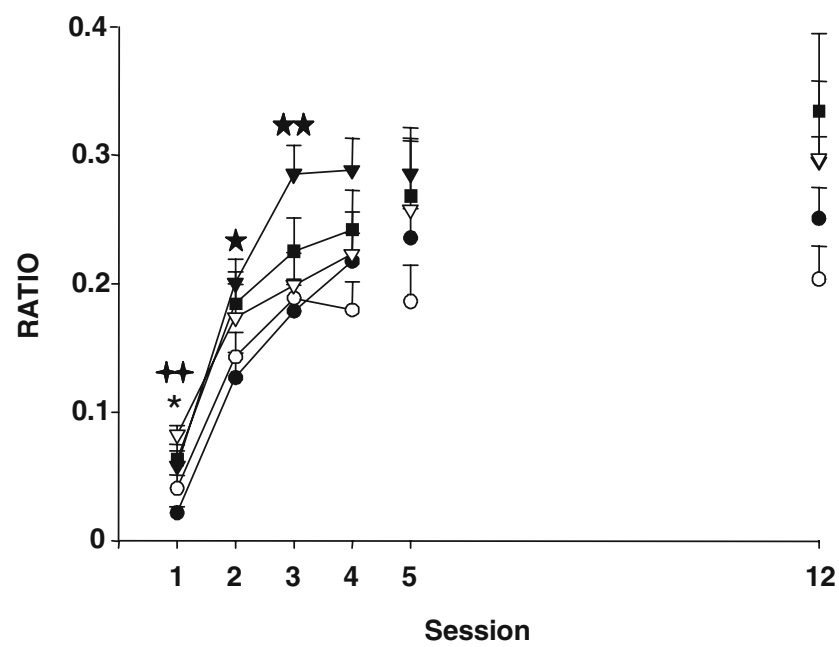

Fig. 1 Acute effects of MDMA during active avoidance acquisition in experimentally naïve mice. Average number of conditioned changes (a), and ratio of conditioned changes with respect to the total number of changes of compartment (b) (+SEM) in the shuttle boxes after the acute injection of saline ( $\mathrm{n}=12)$, MDMA $1 \mathrm{mg} / \mathrm{kg}(\mathrm{n}=11), 3 \mathrm{mg} / \mathrm{kg}$ $(\mathrm{n}=17), 10 \mathrm{mg} / \mathrm{kg}(\mathrm{n}=10)$ and $30 \mathrm{mg} / \mathrm{kg}$ (twice a day for 4 days) $(n=10)$. Mice were trained during 4 days in 100 trial sessions. On days 5 and 12 all mice received saline and were tested on the task. is $\mathrm{p}<0.05$ (MDMA $1 \mathrm{mg} / \mathrm{kg}$ vs. saline). $\star \mathrm{p}<0.001$ (MDMA $3 \mathrm{mg} / \mathrm{kg}$ vs. saline). $++p<0.01,+++p<0.001$ (MDMA $10 \mathrm{mg} / \mathrm{kg}$ vs. saline). * $\mathrm{p}<0.05, * \star \star \mathrm{p}<0.001$ (MDMA $30 \mathrm{mg} / \mathrm{kg}$ vs. saline, Dunnett post-hoc test)
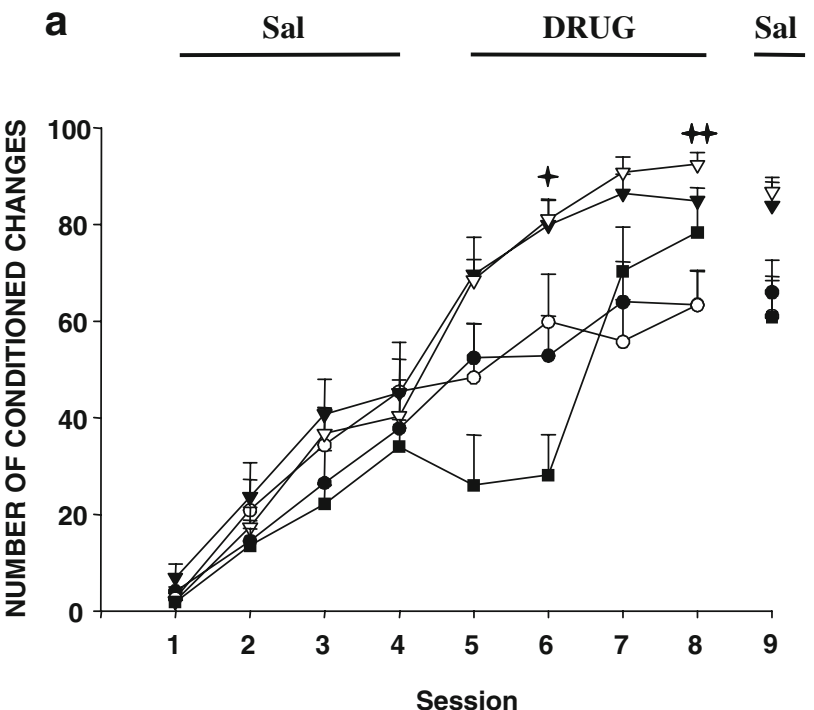

b

Sal

DRUG

Sal

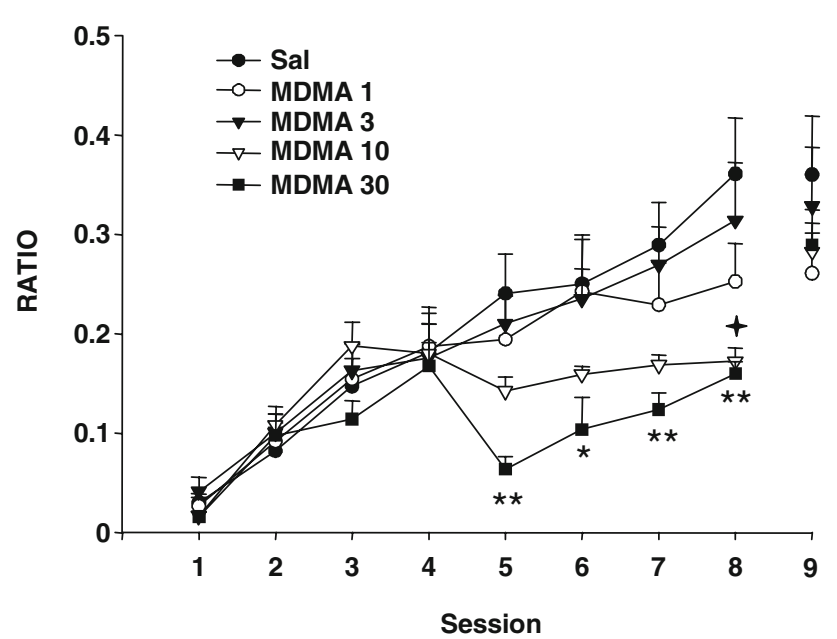

Fig. 2 Acute effects of MDMA on active avoidance performance after a drug-free acquisition. Average number of conditioned changes (a) and ratio of conditioned changes (b) $(+\mathrm{SEM})$ in the shuttle boxes in 100 trial sessions during 4 days of drug-free training and in 4 consecutive training sessions after the acute injection of saline $(n=11)$, MDMA $1 \mathrm{mg} / \mathrm{kg}(\mathrm{n}=7), 3 \mathrm{mg} / \mathrm{kg}(\mathrm{n}=7), 10 \mathrm{mg} / \mathrm{kg}(\mathrm{n}=7)$ and $30 \mathrm{mg} / \mathrm{kg}$ (twice a day for 4 days) $(n=9)$. On day 9 all mice were tested on the task following saline administration. $+\mathrm{p}<0.05,++\mathrm{p}<0.01$ (MDMA $10 \mathrm{mg} / \mathrm{kg}$ vs. saline). ${ }^{\star} \mathrm{p}<0.05$, *夫 $\mathrm{p}<0.01$ (MDMA $30 \mathrm{mg} / \mathrm{kg}$ vs. saline, Dunnett post-hoc test) 

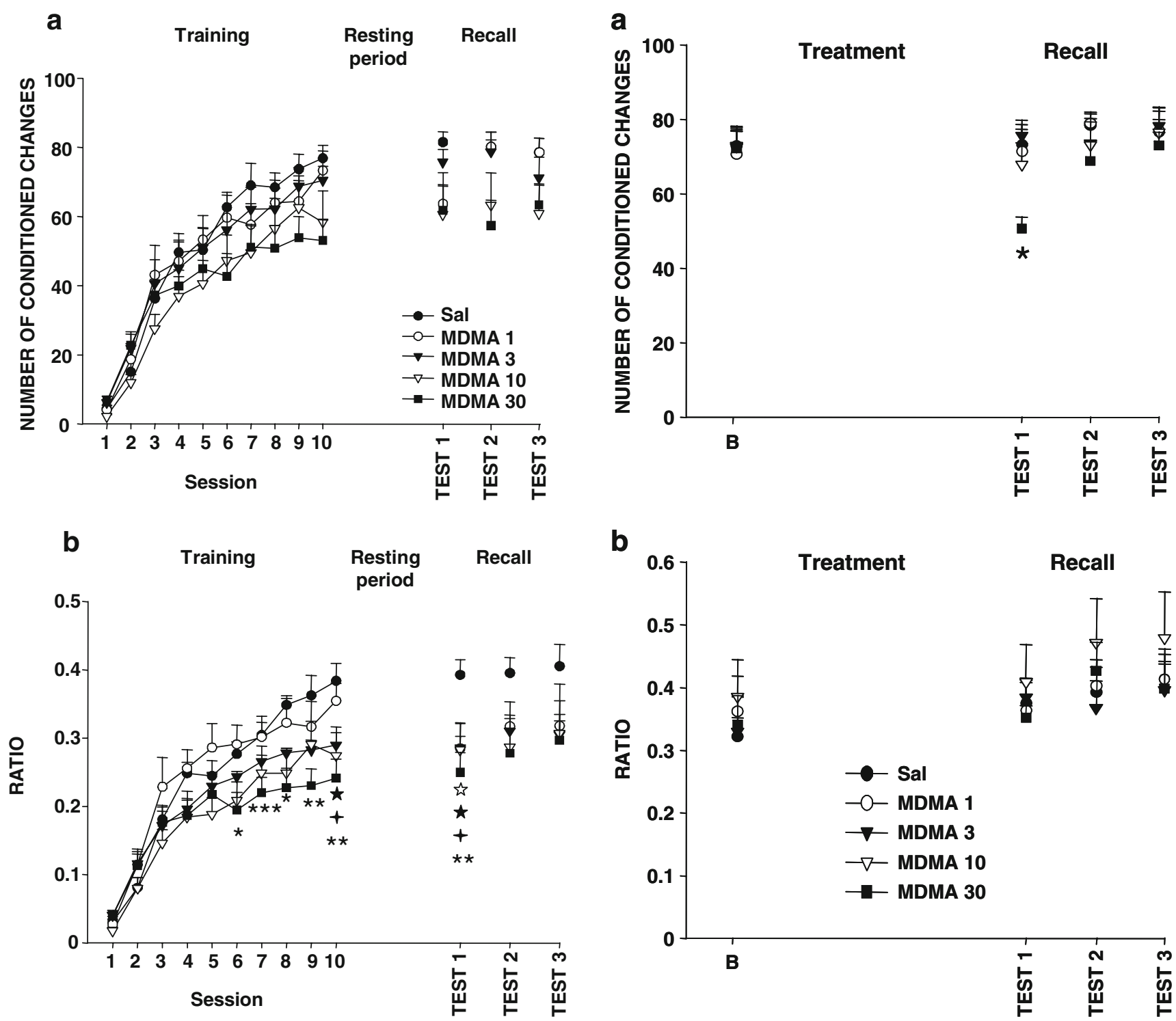

Fig. 4 Effects of repeated pre-treatment with MDMA on active avoidance acquisition and recall. Average number of conditioned changes (a) and ratio of conditioned changes (b) (+SEM) in the shuttle boxes in 100 trial sessions during 10 days of training following treatment with saline ( $\mathrm{n}=9)$, MDMA $1 \mathrm{mg} / \mathrm{kg}(\mathrm{n}=9), 3 \mathrm{mg} / \mathrm{kg}(\mathrm{n}=6)$, $10 \mathrm{mg} / \mathrm{kg}(\mathrm{n}=10)$ and $30 \mathrm{mg} / \mathrm{kg}(\mathrm{n}=11)$ twice a day for 4 days. Following a 5 days resting period all mice underwent 3 recall tests on alternate days. is $\mathrm{p}<0.05$ (MDMA $1 \mathrm{mg} / \mathrm{kg}$ vs. saline). $\star \mathrm{p}<0.05$ (MDMA $3 \mathrm{mg} / \mathrm{kg}$ vs. saline). $+\mathrm{p}<0.05$ (MDMA $10 \mathrm{mg} / \mathrm{kg}$ vs. saline). ${ }^{\star} \mathrm{p}<0.05,{ }^{*} \mathrm{p}<0.01,{ }^{* \star \star} \mathrm{p}<0.001$ (MDMA $30 \mathrm{mg} / \mathrm{kg}$ vs. saline, Dunnett post-hoc test)

Fig. 5 Effects of a repeated treatment with MDMA on active avoidance recall. Average number of conditioned changes (a) and ratio of conditioned changes (b) + SEM in the shuttle boxes during baseline (B: the 3 last days of the training), and recall tests on alternate days following treatment with saline ( $\mathrm{n}=8)$, MDMA $1 \mathrm{mg} / \mathrm{kg}(\mathrm{n}=9)$, $3 \mathrm{mg} / \mathrm{kg}(\mathrm{n}=7), 10 \mathrm{mg} / \mathrm{kg}(\mathrm{n}=8)$ and $30 \mathrm{mg} / \mathrm{kg}(\mathrm{n}=7)$ twice a day for 4 days. ${ }^{*} \mathrm{p}<0.05$ (MDMA $30 \mathrm{mg} / \mathrm{kg}$ vs. saline, Dunnett post-hoc test) 